\title{
Faktor-faktor yang Mempengaruhi Mahasiswa Memilih Kuliah pada Prodi PPKn FIS Universitas Negeri Padang
}

\author{
Pandra Oktum Zalmi, Junaidi Indrawadi \\ Program Studi Pendidikan Pancasila dan Kewarganegaraan \\ Universitas Negeri Padang \\ E-mail: ZalmiPandra@gmail.com
}

\begin{abstract}
ABSTRAK
Penelitian ini dilatarbelakangi oleh rendahnya minat Mahasiswa dalam memilih Kuliah pada Program studi Pendidikan Pancasila dan Kewarganegaan. Penelitian ini bertujuan untuk mengetahui faktor-faktor yang mempengaruhi Mahasiswa memilih kuliah pada Program Studi Pendidikan Pancasila dan Kewarganegaraan. Jenis Penelitian yang digunakan ialah Mixed Methods model Sequential Ekplanatory (Urutan Pembuktian). Hasil Penelitian menunjukkan bahwa; Minat mempengaruhi Mahasiswa dalam memilih kuliah pada Program studi Pendidikan Pancasila dan Kewarnegaraan, orang-orang terdekat seperti orang tua mempengaruhi Mahasiswa memilih kuliah pada Program studi Pendidikan Pancasila dan Kewarganegaran serta Pekerjaan yang diharapkan seperti Guru dan Dosen Pendidikan Pancasila dan Kewarganegaran mempengaruhi Mahasiswa dalam memilih kuliah pada Program studi Pendidikan Pancasila dan Kewarganegaraan. Kesimpulannya bahwa dari Mahasiswa yang ada memiliki minat yang tinggi untuk memilih kuliah di Program studi Pendidikan Pancasila dan Kewarganegaraan selanjutnya Mahasiswa dalam memilih Program studi Pendidikan Pancasila dan Kewarganegaraan dipengaruhi oleh faktor orang tua kemudian Pekerjaan yang diharapkan oleh Mahasiswa setelah lulus dari Program studi Pendidikan Pancasila dan Kewarganegaraan ialah Tenaga pendidik seperti Guru dan Dosen Pendidikan Pancasila dan Kewarganegaraan.
\end{abstract}

Kata Kunci: mahasiswa, PPKn, kuliah

\section{ABSTRACT}

This research is motivated by the low interest of students in choosing a program of study Lecture on Pancasila and Citizenship Education. This study aims to determine the factors that affect college students choose the program Pancasila and Citizenship Education Study. Research type used is a model Sequential Mixed Methods Ekplanatory (Order of Proof). Research results show that; Interest influence in choosing college student at Pancasila Education Study Programs and nationalities, People nearby as parents affect students choose a college on study program Pancasila and Citizenship Education and Employment is expected as Teachers and Lecturers Pancasila and Citizenship Education in choosing a college student influence on program Pancasila and Citizenship Education Study. The conclusion that fromStudents there have a high interest to choose a course in study program Pancasila and Citizenship Education next student in choosing a study program Pancasila and Citizenship 
Education influenced by parents then work expected by the student after graduating from the program of study Pancasila and Citizenship Education is Educators like teachers and Lecturers Pancasila and Citizenship Education.

Keywords : students, PPKn, study

This work is licensed under the Creative Commons Attribution-ShareAlike 4.0 International License. @2019 by author and Universitas Negeri Padang.

\section{PENDAHULUAN}

Pada umumnya pengambilan keputusan merupakan sebuah proses yang dilakukan untuk memecahkan masalah atau persoalan dengan berbagai pertimbangan-pertimbangan tertentu sehingga hasil dari pengambilan keputusan tersebut dapat membuat puas individu. Pertimbangan yang dimaksud diatas ialah pertimbangan yang berasal dari dalam (intern) dan luar diri (ekstern), pertimbangan yang berasal dari dalam diri seperti minat, bakat dan motivasi. Sedangkan pertimbangan yang berasal dari luar diri seperti factor lingkungan keluarga, lingkungan sosial atau media.

Supranto (2013) pengambilan keputusan ialah terletak dalam perumusan berbagai alternative tindakan sesuai dengan yang sedang dalam perhatian dan dalam pemilihan alternative yang tepat setelah suatu evaluasi mengenai efektifitasnya dalam mencapai tujuang yang dikehendaki pengambil keputusan. Salah satu komponen terpenting dari proses pembuat keputusan ialah kegiatan pengumpulan informasi dari mana suatu apresiasi mengenai situasi keputusan dapat dibuat. Lahirnya suatu keputusan tidak serta merta berlangsung secara, sebab sebuah keputusan itu selalu saja lahir berdasarkan dari proses memakan waktu, tenaga pikiran hingga akhirnya terjadi suatu pengkristalan dan lahirlah keputusan tersebut. Saat pengambilan keputusan adalah saat dimana kita sepenuhnya memilih kendali dalam bertindak (Irham, 2011).

Bagi Mahasiswa, keputusan mereka dalam memilih kuliah pada program studi di Perguruan Tinggi tentu memiliki beberapa pertimbangan sebelum dilakukannya pengambilan keputusan. Dalam mengambil keputusan, salah satu pertimbangan yang selalu diperhatikan mahasiswa ialah minat, pekerjaan atau orang-orang yang mempengaruhinya. Mahasiswa akan memilih prodi tertentu sesuai dengan minatnya dikarenakan minat akan membuat Mahasiswa bisa menjalankan perkuliahannya dengan baik dan bisa berprestasi. Pekerjaan tentu menjadi factor penting sebelum memilih program studi dikarenakan mahasiswa juga memikirkan setelah lulus nanti lapangan pekerjaan yang sesuai dengan keahliannya. Kemudian orang-orang berpengaruh seperti orang tua dan teman sebaya juga menjadi dasar pertimbangan mahasiswa karena mereka merupakan orang-orang yang selalu dekat dan memberi masukan kepada individu Mahasiswa.

Penulis tertarik dengan Penelitian ini karena Program studi Pendidikan Pancasila dan Kewarganegaraan merupakan salah satu program studi yang multidisiplin 
ilmu artinya program studi ini banyak memiliki rumpun ilmu yang bisa di pelajari seperti Ilmu Pendidikan, Moral, Etika, Sosial, Hukum, Politik, Gender, Kearifan lokal, Kepemimpinan, Demokrasi, Multikultural, Lingkungan Hidup, Ilmu Pemerintahan, Hubungan Internasional, Sejarah Lokal-Nasional dan Wawasan Kebangsaan. Oleh sebab itu, akan mempermudah lulusannya untuk mencari lapangan pekerjaan. Salah satu contoh kiprah Alumni Program studi Pendidikan Pancasila dan Kewarganegaraan ialah Rusma Yul Anwar beliau pernah menjabat sebagai Kepala Dinas Pendidikan dan sekarang Beliau menjabat sebagai Wakil Bupati Pesisir Selatan. Suparman beliau sekarang menjabat sebagai wakil ketua Dewan Perwakilan Rakyat Daerah Kota Payakumbuh periode 2014-2019. Namun, kenyataan dilapangan menunjukkan bahwa dari Mahasiswa yang ada tidak banyak memilih kuliah pada Program Studi Pendidikan Pancasilan dan Kewarganegaraan Fakultas Ilmu Sosial Universitas Negeri Padang.

Keterbatasan solusi yang pernah ada yaitu tidak banyak penulis mengemukakan pendapat tentang faktor-faktor yang mempengaruhi mahasiswa dalam memilih Kuliah pada Program Studi Pendidikan Pancasila dan Kewarganegaraan. Dimana Kita perlu mengetahui faktorfaktor lain yang bisa mempengaruhi Mahasiswa untuk Kuliah sehingga akan menambah wawasan Penulis dalam melakukan Penelitian. Kelebihan solusi dalam penelitian ini yaitu Penulis dapat menjelaskan secara rinci faktor-faktor yang mempengaruhi Mahasiswa dalam memilih kuliah pada Program Studi Pendidikan Pancasila dan Kewarganegaraan seperti faktor minat, pengaruh orang-orang terdekat dan Pekerjaan yang diharapkan.

Adapun tujuan penulisan artikel ini ialah untuk mengetahui faktorfaktor yang mempengaruhi Mahasiswa dalam memilih Kuliah pada Program Studi Pendidikan Pancasila dan Kewarganegaraan Fakultas Ilmu Sosial Universitas Negeri Padang. Manfaat dari penelitian ini ialah dapat menjadi pedoman dalam menetapkan kuota dan passing grade serta kebijakan lainnya bagi Program Studi Pendidikan Pancasila dan Kewarganegaraan, Fakultas Ilmu Sosial dan Universitas Negeri Padang.

\section{METODE PENELITIAN}

Jenis Penelitian ini menggunakan Mixed Method dengan model Sequental Ekplanatory (Urutan Pembuktian). Jenis Penelitian Mixed Method ialah pendekatan dalam penelitian yang mengkombinasikan atau menghubungkan antara metode penelitian kuantitatif dan kualitatif menurut Creswell dalam Sugiyono (2017:404). Model Sequential Ekplanatory (Urutan Pembuktian) yaitu metode penelitian kombinasi yang menggabungkan metode penelitian kuantitatif dan kualitatif secara berurutan, dimana pada tahap pertama penelitian ini dilakukan dengan metode penelitian kuantitatif dan tahap kedua menggunakan metode kualitatif. Responden dan informan yang digunakan ialah Mahasiswa tahun masuk 2015-2018 Prodi PPKn masing-masing sebanyak 176 (seratus tujuh puluh enam) dan 8 (delapan) orang. Lokasi yang dipakai 
ialah lingkungan program studi Pendidikan Pancasila dan Kewarganegaraan, ruang kelas serta kost-kosan Mahasiswa. Teknik pengumpulan data yang digunakan ialah angket, wawancara serta observasi. Teknik analisis data yang dipakai ialah pengumpulan data secara kuantitatif melalui penyebaran angket dan pengumpulan data secara kualitatif melalui wawancara.

\section{HASIL DAN PEMBAHASAN}

Penelitian ini dilakukan di Lingkungan Program Studi Pendidikan Pancasila dan Kewarganegaraan Fakultas Ilmu Sosial Universitas Negeri Padang dengan jumlah populasi 512 orang Mahasiswa yang merupakan jumlah mahasiswa Tahun masuk 2015 sampai 2018. Sampel penelitian sebanyak 176 Orang dari total populasi.

Faktor-faktor yang Mempengaruhi Mahasiswa dalam Memilih Kuliah pada Program Studi Pendidikan Pancasila dan Kewarganegaraan Fakultas Ilmu Sosial Universitas Negeri Padang

Pada analisis data yang sudah diperoleh diolah sesuai dengan kebutuhan penelitian, yaitu untuk menjawab rumusan masalah penelitian, seperti Apakah faktor minat mempengaruhi Mahasiswa memilih Kuliah pada Program Studi Pandidikan Pancasila dan Kewarganegaraan? Apakah faktor orang-orang yang berpengaruh mempengaruhi Mahasiswa memilih Kuliah pada Program Studi Pandidikan Pancasila dan Kewarganegaraan? Apakah faktor Pekerjaan yang diharapkan mempengaruhi Mahasiswa memilih Kuliah pada Program Studi
Pandidikan Pancasila dan Kewarganegaraan?

\section{Minat}

\section{Gambar 1. Histogram tentang Minat}

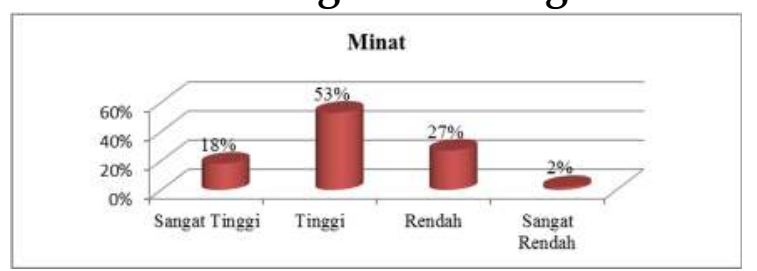

Gambar 2. Histogram tentang Sub Indikator Minat

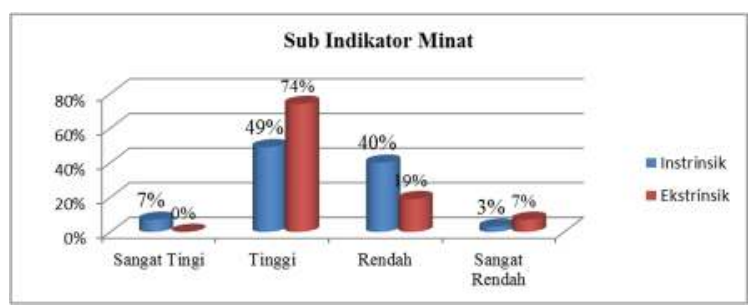

Berdasarkan data distribusi frekuensi dari 176 responden dengan 10 pertanyaan dapat dilihat bahwa secara keseluruhan dari Mahasiswa yang ada minat mempengaruhi mahasiswa memilih kuliah pada Program studi Pendidikan Pancasila dan Kewarganegaraan dengan persentase 53\%. Pengaruh tingginya minat dilihat dari faktor internal dan eksternal dengan persentase masingmasing $49 \%$ dan $74 \%$.

Minat merupakan salah satu faktor yang mempengaruhi mahasiswa dalam memilih kuliah pada program studi Pendidikan Pancasila dan kewarganegaraan. Minat mahasiswa muncul untuk kuliah pada Program studi Pendidikan Pancasila dan Kewarganegaraan di karenakan dahulu pernah mempunyai prestasi di bagian kewarganegaraan seperti lomba debat dan lomba empat pilar kebangsaan dan lomba tersebut diikuti pada tingkat Kabupaten/Kota, kecamatan serta sekolah selanjutnya mahasiswa yang mengikuti lomba tersebut pernah mendapatkan penghargaan dari pihak yang 
menyelenggarakannya sehingga timbul minat mahasiswa untuk memilih program studi Pendidikan Pancasila dan Kewarganegaraan. Mahasiswa cenderung mempertimbangkan kemampuannya dalam memilih jurusan di perguruan tinggi sehingga ketika kuliah mempunyai semangat untuk mempelajari lebih lanjut Pendidikan Pancasila dan Kewarganegaraan.

\section{Pengaruh Orang-orang Terdekat}

Gambar 3. Histogram tentang pengaruh orang terdekat

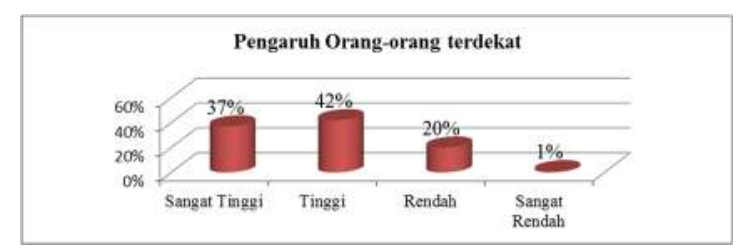

Sumber: Analisis data Primer 2019

\section{Gambar 4. Sub Indikator Pengaruh Orang-orang terdekat}

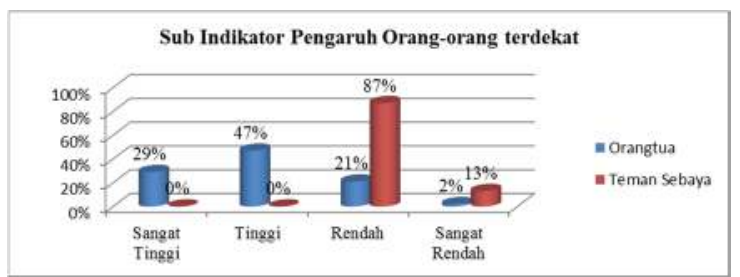

Sumber: Analisis data Primer 2019

Berdasarkan data distribusi frekuensi dari 176 responden dengan 10 pertanyaan dapat dilihat bahwa secara keseluruhan pengaruh orangorang terdekat mempengaruhi mahasiswa memilih kuliah pada Pendidikan Pancasila dan Kewarganegaraan dengan persentase $42,0 \%$. Tingginya pengaruh orangorang terdekat merujuk kepada pengaruh orang tua dengan kategori tinggi sebesar $47 \%$ dan teman sebaya dengan kategori rendah sebesar $87 \%$.

Orang tua berperan penting mempengaruhi anak-anaknya dalam mengambil berbagai keputusan termasuk dalam memilih kuliah pada program studi Pendidikan Pancasila dan Kewarganegaraan. Orang tua Mahasiswa tentu memiliki berbagai latar belakang pekerjaan, pendapatan serta jumlah tanggungan anak yang dimilikinya. Rata-rata jenis pekerjaan yang di miliki oleh orang tua mahasiswa ialah petani kemudian rata-rata penghasilan yang di hasilkan oleh orang tua mahasiswa ialah $\mathrm{Rp}$. 500.000, sampai Rp. 1.000.000./bulan hal ini termasuk kategori penghasilan menengah kebawah serta rata-rata jumlah tanggungan anak yang di miliki orang tua mahasiswa ialah dua orang anak maka dari itu, semakin bagus jenis pekerjaan yang dimiliki orang tua maka semakin besar peluang anaknya untuk melanjutkan pendidikan ke program studi yang lebih unggul kemudian semakin besar jenis pendapatan yang dihasilkan orang tua maka semakin bebas anaknya mengekspresikan diri untuk memilih prodi yang unggul di Perguruan Tinggi serta semakin sedikit jumlah tanggungan anak yang dimiliki oleh orang tua maka besar peluang anaknya untuk melanjutkan studi di Prodi yang unggul.

\section{Pekerjaan yang diharapkan}

Gambar 5. Histogram tentang pekerjaan yang akan digeluti setelah Wisuda

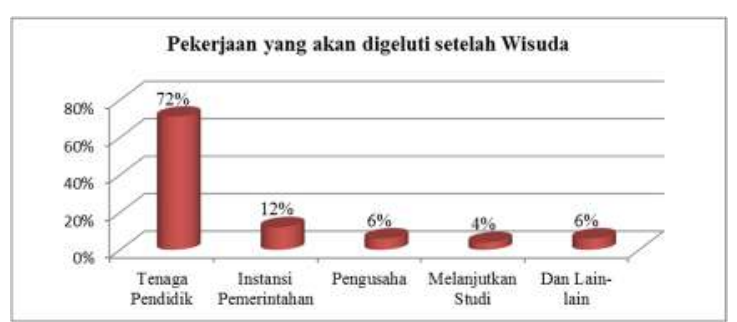

Sumber: Analisis data Primer 2019 
Berdasarkan data distribusi frekuensi dari 175 responden dengan 5 pertanyaan dapat dilihat bahwa Pekerjaan yang diharapkan memiliki pengaruh bagi mahasiswa yang memilih kuliah pada Program studi Pendidikan Pancasila dan Kewarganegaraan dengan persentase $72 \%$.

Pada saat sekarang mahasiswa yang lulus di Perguruan Tinggi cenderung memilih pekerjaan yang sesuai dengan prodi yang telah di pelajarinya waktu kuliah termasuk lulusan Prodi Pendidikan Pancasila dan Kewarganegaraan yang akan memilih pekerjaan sebagai Guru dan Dosen Pendidikan Pancasila dan Kewarganegaraan. Mahasiswa Program studi Pendidikan Pancasila dan Kewarganegaraan memilih pekerjaan sebagai Guru dan Dosen Pendidikan Pancasila dan Kewarganegaraan di karenakan Prodi Pendidikan Pancasila dan Kewarganegaraan memang basiknya untuk menjadi Guru dan Dosen Pendidikan Pancasila dan Kewarganegaraan, guru dan dosen salah satu pekerjaan mulia yang akan melahirkan pahala jahiriyah, menjadi Guru atau Dosen Pendidikan Pancasila dan Kewarganegaraan bisa mendidik moral dan etika anak-anak murid, salah satu jenis pekerjaan yang waktunya fleksibel, menjadi guru dan dosen bisa menghadapi berbagai karakter anak murid, Pekerjaan sebagai guru atau dosen membuat kita bisa menciptakan beragam inovasi dalam dunia pendidikan serta Guru Pancasila Pendidikan dan Kewarganegaraan masih minim di daerah responden.

\section{Minat}

Ada beberapa factor yang membuat minat Mahasiswa tinggi untuk kuliah pada Program studi Pendidikan Pancasila dan Kewarganegaraan diantaranya ialah prestasi Belajar. Prestasi belajar yang membuat tingginya minat Mahasiswa untuk kuliah pada Prodi Pendidikan Pancasila dan Kewarganegaraan ialah prestasi tentang debat dan cerdas cermat empat pilar kebangsaan kemudian lomba debat yang pernah di ikuti oleh Mahasiswa ialah lomba debat konstitusi yang di adakan oleh Perguruan Tinggi di Provinsi Bengkulu dan lomba debat yang di adakan tingkat kecamatan di Kabupaten Sawahlunto serta lomba cerdas cermat yang di adakan tingkat sekolah.

Hal diatas senada dengan pendapat Slameto (2013) menyatakan bahwa minat tidak di bawa sejak lahir namun di peroleh kemudian hari. Minat terhadap sesuatu di pelajari dan mempengaruhi penerimaan minatminat baru. Jadi minat terhadap sesuatu merupakan hasil belajar dan menyokong belajar selanjutnya. Buktibukti memperlihatkan bahwa keberhasilan di sekolah, khususnya untuk waktu yang lama seringkali menghasilkan suatu penerimaan yang tinggi akan dirinya sendiri dan kemampuan dirinya. Hal ini juga sesuai juga dengan pendapat Djaali (2012) mengatakan bahwa pada gilirannya, prestasi yang berhasil akan menambah minat individu yang bisa berlanjut sepanjang hayat.

\section{Pengaruh Orang-orang terdekat}

Hasil penelitian menunjukkan bahwa orang tua merupakan pengaruh yang paling tinggi bagi mahasiswa dalam memilih kuliah pada Program 
Studi Pendidikan Pancasila dan Kewarganegaraan. Orang tua dalam penelitian ini merujuk kepada jumlah pendapatan, jenis pekerjaan dan jumlah anak yang ditanggung, semakin tinggi tingkat pendapatan dan jenis pekerjaan yang dimiliki oleh orang tua maka semakin besar peluang anak-anaknya dalam memilih program studi secara bebas di perguruan tinggi kemudian semakin sedikit jumlah tanggungan anak yang dimiliki oleh orang tua maka semakin bebas anak-anaknya dalam memilih Prodi di Perguruan tinggi. Jenis pekerjaan orang tua mahasiswa yang di tekuni rata-rata petani, pedagang dan Ibu rumah tangga dan jumlah pendapatan yang di hasilkan oleh orang tua Mahasiswa Pendidikan Pancasila dan Kewarganegaraan ialah rata-rata Rp. 500.000.- hingga Rp1.000.000 per bulan serta jumlah tanggungan yang dimiliki oleh orang tua rata-rata dua orang.

Hal ini senada dengan hasil penelitian Irmawati (2008) mengatakan secara teoritis memang dinyatakan bahwa orang tua yang status sosial ekonominya tinggi mampu membimbing, mengarahkan dan memberi masukan kepada anaknya dalam memilih program studi di Perguruan Tinggi selain itu mereka juga mampu menyediakan kondisi atau lingkungan belajar serta sarana dan prasarana belajar yang memadai untuk menunjang pendidikan anaknya. Hal yang sama juga disampaikan oleh Agustinus (2003) menyatakan bahwa keadaan keluarga berpengaruh pada perkembangan anak, ini dapat diartikan bahwa kondisi social ekonomi orang tua yang cukup anak akan mendapat kesempatan yang lebih
Volume 1 No. 22018

luas untuk mengembangkan kemampuannya dibandingkan dengan anak yang berasal dari ekonomi lemah dan rendah akan kesulitan dalam memenuhi kebutuhan pendidikan anaknya baik kebutuhan materiil maupun moril.

\section{Pekerjaan yang diharapkan}

Pekerjaan yang di harapkan mempengaruhi Mahasiswa dalam memilih kuliah pada Program studi Pendidikan Pancasila dan Kewarganegaraan kemudian pekerjaan yang di harapkan merujuk kepada tenaga pendidik seperti Guru dan Dosen Pendidikan Pancasila dan Kewarganegaraan. Mahasiswa memilih pekerjaan sebagai Guru dan Dosen PPKn di karenakan Program studi Pendidikan Pancasila dan Kewarganegaraan memang diciptakan untuk menjadikan Individu sebagai tenaga pendidik, pekerjaan sebagai guru dan dosen merupakan pekerjaan sangat mulia yang akan melahirkan pahala jahiriyah, bisa menjadi individu yang melakukan pembelajaran moral, etika dan sopan santun secara langsung kepada siswa, bisa melakukan beragam inovasi baru dalam dunia Pendidikan serta tersedia peluang yang besar untuk menjadi guru di berbagai daerah.

Hal ini sesuai dengan hasil penelitian Irmawati mengatakan bahwa mahasiswa yang menginginkan menjadi seorang pengajar maka akan mengambil program studi yang berhubungan dengan keguruan dan mahasiswa yang ingin bekerja bukan sebaga guru maka akan memilih Program studi non kependidikan. Kebanyakan mahasiswa memang ingin bekerja secara tetap sesuai dengan bidang 
studi yang mereka pelajari di perguruan tinggi. Tampak jelas bahwa studi di pendidikan tinggi memang dimaksudkan sebagai persiapan untuk mendapatkan pekerjaan yang layak dimata masyarakat nantinya (Irmawati, 2008).

\section{KESIMPULAN}

Dari hasil penelitian yang telah dilakukan oleh penulis dapat di tarik kesimpulan bahwa mayoritas Mahasiswa Pendidikan Pancasila dan Kewarganegaraan memiliki minat yang tinggi dalam memilih kuliah pada Program Studi Pendidikan Pancasila dan Kewarganegaraan. Minat Mahasiswa tersebut dipengaruhi oleh prestasi seperti lomba debat dan lomba cerdas cermat empat pilar kebangsaan yang diselenggarakan tingkat sekolah, kecamatan, kabupaten/kota. Mahasiswa memilih kuliah pada Program Studi Pendidikan Pancasila dan Kewarganegaraan di pengaruhi oleh orang tua, pengaruh orang tua yang paling kuat ialah pendapatan, pekerjaan serta jumlah tanggungan anak yang dimiliki. Mahasiswa setelah menjadi lulusan Program Studi Pendidikan Pancasila dan Kewarganegaraan mayoritas berharap menjadi tenaga Pendidik seperti Guru dan Dosen Pendidikan Pancasila dan Kewarganegaraan.

\section{DAFTAR PUSTAKA}

Djaali. (2012). Psikologi Pendidikan. Jakarta: Bumi Aksara.

Irham. (2011). Manajemen Pengambilan Keputusan. Bandung: Alfabeta.

Irmawati, Basilia Ria (2008). Faktorfaktor yang Mempengaruhi Mahasiswa dalam Memilih Program Studi di Perguruan Tinggi. Yogyakarta: Jurusan
Pendidikan Ilmu Pengetahuan Sosial FKIP Universitas Sanata Dharma.

Slameto. (2010). Belajar dan Faktor-faktor yang Mempengaruhi. Jakarta: Rineka Cipta

Sugiyono. (2017). Metode Penelitian Kombinasi (Mixed Metode). Bandung: Alfabeta.

Supranto, J. (2013). Teknik Pengambilan Keputusan. Jakarta: PT Rineka Cipta. 